\title{
Use of Trigger Points Therapy for cervical spondylarthrosis with aggravated symptoms of Varicella-Zoster virus infection - Case Report
}

\author{
Ana Maria VUTAN ${ }^{1}$, Corina PANTEA ${ }^{2}$
}

\begin{abstract}
Introduction. There are only few articles in the literature that discuss or present the complications that occur after primary infection with Varicella-Zoster Virus. Most studies present the complications after the virus reactivates in people with shingles. Their approaches shows only the immediate medical perspective and not the intervention on the remaining of sequelae. The varicella-zoster virus can affect both children and adults, and the most effective way to prevent it is to administer the vaccine. Aim. The purpose of this paper is to present the case of a 28-year-old young male who had a first infection with the Varicella-Zoster virus and he developed a series of symptoms (migraines, vertigo, tinnitus, insomnia, anxiety) that have seriously affected his quality of life. Method. The Visual Analogue Scale of pain (VAS),Neck Disability IndexVernon and Mior Cervical Spine Questionnaire (NDI) were used in the case assessment. As established treatment, Trigger Points Therapy, myofascial stretching (15 sessions) and physical therapy (10 sessions) were performed. Results. Following the initial, intermediate and final evaluation, there was a marked decrease in the value of the VAS scale as well as the value of the DNI questionnaire, which represents the decrease of pain and increase of quality of life. In conclusion, Trigger Points Therapy and myofascial stretching along with exercise can significantly reduce migraine pain and can help eliminate other symptoms such as tinnitus, vertigo, adynamism, even though, they occurred secondary to a viral infection.
\end{abstract}

Key words: Varicella -Zoster Virus infection complications, trigger points, migraines,

\section{Rezumat}

Introducere. În literatura de specialitate sunt puține articole care aduc în discuție sau prezintă complicațiile ce apar după infectarea primară cu virusul Varicelo-Zosterian. Cele mai multe studii prezintă complicații apărute la reactivarea virusului, la persoane cu Zona Zoster. Abordarea lor este din perspectiva medicală imediată și nu a sechelelor rămase după infectare. Virusul varicelo-zosterian poate afecta atât copii cât și adulți iar cea mai eficientă modalitate de prevenire este administrarea vaccinului. Scopul lucrări. Scopul acestei lucrări este de a prezenta cazul unui tânăr de sex masculin, cu vârsta de 28 de ani, care după o primă infectare cu virusul Varicelo-Zosterian, a dezvoltat o serie de simptome (migrene, vertij, acufene, insomnii, anxietate) care au ajuns să îi afecteze grav calitatea vieții. Metodă. În evaluarea cazului s-a utilizat scala VAS și Neck Disability Index- Vernon and Mior Cervical Spine Questionnaire (NDI). Ca tratament s-a intervenit cu Terapia Trigger Points și stretching miofascial (15 sedințe) și kinetoterapie (10 sedințe). Rezultate. În urma evaluării inițiale, intermediare și finale s-a observat scăderea marcată a valorii scalei VAS cât și valorii chestionarului NDI, aceasta reprezentând scăderea durerii și creșterea calității vieții. În concluzie, Terapia trigger points și stretching-ul miofascial alături de exercițiile fizice pot scădea semnificativ durerea de tip migrenă și pot ajuta la dispariția altor simptome precum acufene, vertij, adinamie, chiar dacă acestea au apărut secundar unei infecții virale.

Cuvinte cheie: complicații ale infectării cu virusul Varicelo-Zosterian, Trigger Points, migrene

\footnotetext{
${ }^{1}$ Physiotherapist, Assistant Professor, PhD student, West University of Timișoara, Physical Education and Sport Faculty, Romania, $e$-mail: ana.vutan@e-uvt.ro

${ }^{2}$ Associate Professor, PhD, West University of Timisoara, Physical Education and Sport Faculty, Romania
} 


\section{Introduction}

Chickenpox is an infectious caused by the VaricellaZoster Virus (VZV). This virus can easily affect both children and adults who have not been immunized by vaccination or have had no history of the disease. The chickenpox vaccine was approved in 1995 and can be administered to children over the age of one year, but also to adults, preventively, or in the first 72 hours after contact with an infected person. The VZV can affect almost the entire population during its lifetime [2]. After an incubation period of 10 to 21 days after infection, chickenpox-specific blisters appear on the skin. One to two days before the appearance of blisters on the skin, the infected person may have a fever, malaise, abdominal pain and headache that disappear 2-4 days after the onset of the rash [1]. Infection with this type of virus normally provides immunity for life, but it can sometimes be reactivated during adulthood because the virus remains latent in the host organism in the cranial or dorsal sensory ganglia [3]. The subsequent activation of the virus causes shingles, with unilateral blistering rashes on a dermatome as well as root pain [1]. Reactivation occurs in $20 \%$ to $50 \%$ of the population over the age of 50 and the same percentage is found in immunocompromised individuals [4]. Sometimes, great pain and discomfort are present for weeks, months and even years, through the development of post-herpetic neuralgia (PHN) which greatly decreases the quality of life. The causes of PHN have not been fully elucidated. Complications such as myelitis, encephalitis, cranial nerve palsy, stroke, gastroenterological disorders (hepatitis, pancreatitis, ulcers), glomerulonephritis may rarely occur [5]. Treatment for VVZ infection is nonspecific, consisting of administration of oral antihistamines, use of calamine lotions, baths with oatmeal. Fever is controlled with acetaminophen [2]. For cases at risk of developing complications, acyclovir $20 \mathrm{gr} / \mathrm{kg}$ body weight is administered to children and $1 \mathrm{~g} / \mathrm{kg}$ body weight to adolescents and young people $[6,7,8]$. There are no studies on complications that occurred in adults after the first infection with VVZ; however, literatures has reported cases that showed complications after virus reactivation, such as: acute meningoencephalitis [9], segmental motor paralysis
[10], nerve palsy oculomotor [11], acute transverse myelitis [12].

\begin{abstract}
Aim
The purpose of this article is to present a case of a 28year old male patient, infected for the first time with the Varicella-Zoster virus. Following this infestation, he developed a series of symptoms that led to a major discomfort for his life.
\end{abstract}

\section{Material and method}

In January 2019, a 28-year-old male patient began to develop low-grade fever, headache and, after 2 days, chickenpox-specific blisters appeared all over his body. The family doctor confirmed the diagnosis and recommended isolation for 14 days, the use of lotions for itchy skin and acetaminophen, as needed. Unfortunately, during the 2 weeks of isolation, the headache intensified and cervical pain was added with stiffening of the neck muscles, tinnitus, pain behind the orbits, paresthesia of the upper limbs, adynamism. The headache did not diminish with the medication prescribed by the family doctor: acetaminophen, ibuprofen, ketoprofen. At the indications of the family doctor, the patient performs an X-ray of the cervical spine, which highlights: profile rectitude, C5-C6, C6-C7 disc thoughts, C5-C6 anterior and posterior marginal osteophytes, C5 intraspongious hernia. With these results, the patient presents to a neurological consultation and is recommended to perform an MRI examination of the cervical and cerebral spine. This new investigation highlights the existence of partial C2-C6 disc degenerative lesions with disc impressions, marginal osteogenic productions, detection of multi-level hernias of discoligamentous material at the postero-median of the C3-C7 level with dural sac impregnation, asymmetry of the lateral ventricles with slight hyperplasia of the left ventricular cavities, supra and infratentorial brain structures without detectable lesions, angio-MRI (3D-TOF) within normal limits. The neurologist recommends physiotherapy and medication (Naproxen). The patient performs 30 physiotherapy sessions (electrotherapy and massage), but his condition worsens. In this period, the following symptoms occurred:insomnia, vertigo, pain in the shoulders and arms, permanent migraine-type headache, 
which did not subside to medication, and anxiety. The patient consults a psychiatrist who recommends anxiolytic medication (Lorazepam) and psychotherapy. After one month, the patient had new neurological consultation performed at a clinic in Hungary that recommends Trigger Points Therapy.

This is when the patient presents to our rehabilitation clinic for an evaluation and the establishment of a treatment based on Trigger Points Therapy. In the initial assessment, the Visual Analogue Pain Scale (VAS) and Neck Disability Index-The Vernon and Mior Cervical Spine Questionnaire (NDI), mobility tests were used. For the VAS evaluation, the patient was asked to rate on a scale from 0 to 10 , the grade attributed to the pain felt at the time. For the NDI questionnaire, the patient had to give a score from 0 to 5 , for 10 questions related to the daily routine. The questions focused on: the intensity of the pain felt daily, whether the pain occurs while performing self-care or lifting weights or while reading or doing activity at work, or driving or having recreational activities, and the ability of the patient to concentrate. The assessment of cervical spine mobility was performed using the goniometer. The patient was also palpated to detect active Trigger Points in the muscles in order to create a treatment sheet. Thus, it was established to perform Trigger Point Therapy on the following muscles:

- Trapezius TrP1, TrP2, TrP3 responsible for symptoms such as migraine-type pain, pain in the temples, back eyes pain, pain in the cervical spine, vertigo, stiffness of the cervical area, pain in the shoulder area.

- Sternocleidomastoideus TrP responsible for dry cough, retro-ocular pain, irradiated pain in the top of the head, visual disturbances, tinnitus, pain in the frontal region.

- Masseter TrP responsible for tinnitus, pain in the tight regions of the neck.

- Temporalis TrP responsible for headaches in the temporal region.

- Head and neck spenius TrP responsible for migraine, irradiated pain in the vertex, diffuse pain inside the head, pain in the occiput zone and behind the eyes, blurred vision.
- Suboccipitalis TrP responsible for migraine, pain in the occipital region, deep headache, pain behind the eyes, limited flexion and tilt of the cervical spine - Subclavius TrP responsible for irradiated pain in the upper limb, pain felt in the middle of the arm, forearm and fingers 1-3

- Supraspinatus TrP responsible for stiffness in the shoulder and restricted movement, deep pain in the shoulder [13,14].

At the end of the session, myofascial stretching exercises were performed, specific to each muscle processed during the session. The patient was instructed on how to perform those exercises at home, individually. Myofascial therapy sessions were held daily.

After the first 5 Trigger Point Therapy sessions, a new evaluation was performed with the VAS scale, NDI and joint testing. Following the analysis of the results, it was established to continue the Trigger Therapy sessions, myofascial stretching and also Physical Therapy exercises. The exercises within the Physical Therapy program focused on the active performance in the cervical spine and shoulder, FNP (hold-relax) techniques and cervical elongations. This time the sessions were performed 3 times a week and the patient was instructed to do self miofascial stretching at home.

After 10 treatment sessions, the patient was reevaluated: VAS, NDI, mobility tests.

\section{Results}

The patient included in the study was initially evaluated at the start of treatment with Trigger Points Therapy using the VAS scale, DNI questionnaire and mobility tests.

The level indicated by the patient as the pain felt before starting the treatment was marked with 8 . After the first 5 sessions of Trigger Points Therapy, the level decreased to 4 and, at the end of 15 treatment sessions, the indicated level was 1 . The results obtained can be seen in Figure I. 


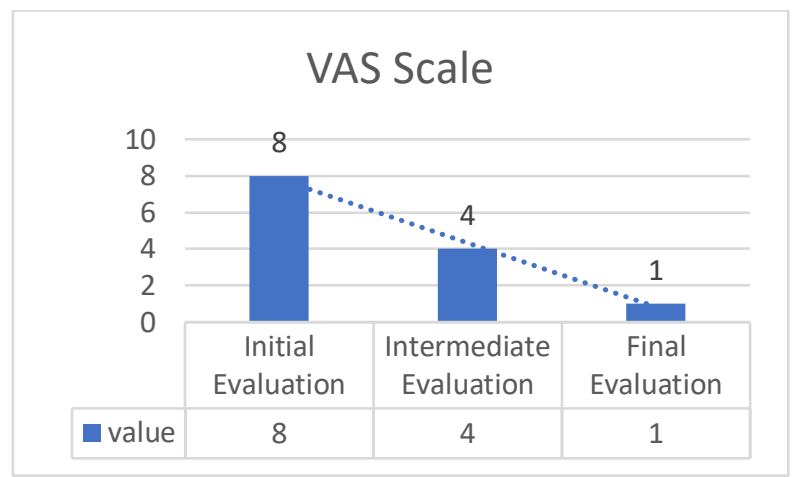

Figure I. Evolution of the VAS scale (initial, intermediate and final)

The very good response of the patient to the therapy can be seen in the chart above. At the end of the $15^{\text {th }}$ treatment session, the pain felt was often ignored by the patient and there were times when he was no longer in pain.

The evaluation of the NDI questionnaire is presented in Figure 2.

\section{Neck Disability Index - Vernon and Mior Cervical Spine Questionaire}

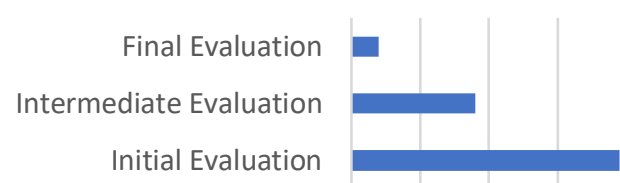

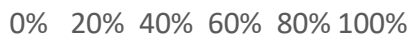

Figure 2. Evolution of the NDI questionnaire

The initial score obtained by the patient in the NDI questionnaire was $78 \%$, almost all the activities performed by the patient being affected by pain. At the end of the 15 sessions the score obtained was $8 \%$, which means that the pain affects much less the activities performed, and the patient can almost have a normal life.

The assessment of joint mobility highlighted the fact that, initially, the anterior flexion, lateral flexion, and rotation of the spine were severely affected and, as the muscles were relaxed, pain disappeared, and they began to work effectively, while the mobility of the spine was significantly improved (Figure 3.)

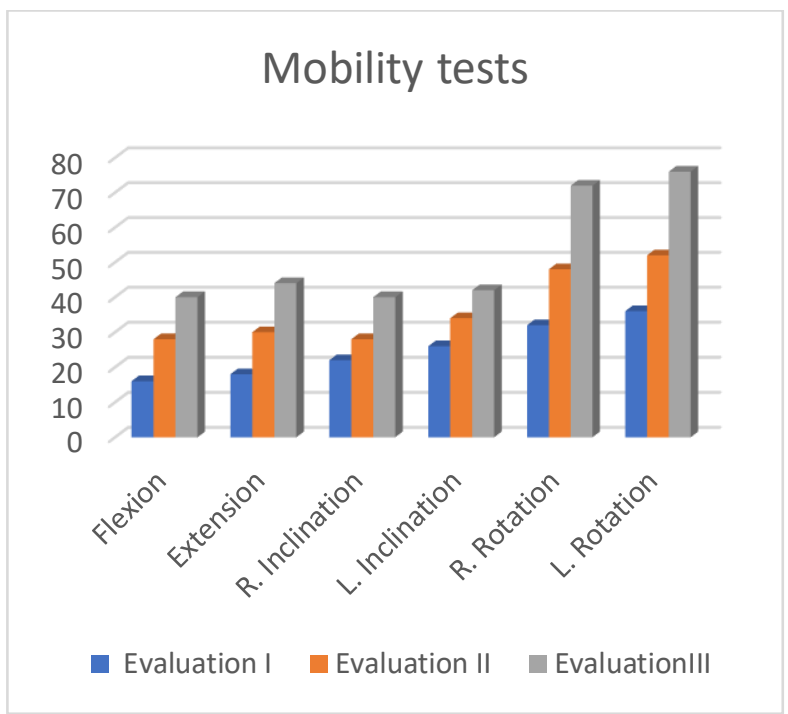

Figure 3. The evaluation of the mobility tests

Inactivation of the Trigger Points and myofascial stretching made possible the increase of the amplitudes of movement right from the first part of the treatment and, later on, the introduction of physical exercises determined a recovery as close as possible to the normal values of movement.

\section{Discussions}

In the literature, cases that have been studied generally showed severe complications of the central nervous system after primary infection with the Varicella-Zoster virus (mainly in immunocompromised children) or reactivation of the virus in adults who developed shingles. The treatment in the presented cases consisted in the administration of medication for the specific symptomatology of each case. Physical treatment is not mentioned in any of the studies found in the documentary researches. In our case report, the primary infection with VVZ in adulthood caused a series of symptoms that, within 3 months, significantly affected the life of the subject who could not carry out daily activities due to permanent migraine pain, insomnia and anxiety. In the case of this patient, the drug treatment recommended by the neurologist, family doctor and psychiatrist did not solve the problems, nor did the physiotherapy treatment (electrotherapy and massage); instead, it responded very well to the applied Trigger Points Therapy. After the first session, the patient managed to sleep without 
waking up all night, the migraine type pain decreased significantly, and, at the end of 5 sessions, other symptoms such as vertigo, tinnitus, retro-ocular pain, shoulder pain were significantly improved. The continuation of therapy sessions with the introduction in the following weeks of active physical exercises and facilitation techniques determined the improvement of the amplitudes of movement of the cervical spine and shoulder, decrease of pain to a level where the patient no longer felt it during recreational activities.

In the literature, there are studies on the use of Trigger Points Therapy in case of migraine pain. Specialists in the field indicate this therapy to subjects who did not respond to drug treatment or in combination with drug treatment. Many subjects develop adverse drug reactions and the approach taken by physiotherapists can improve the quality of life of these patients. [16]

\section{Conclusions}

In our case report, the infection with VVS triggered a series of symptoms that were extremely annoying for the patient. The physiotherapeutic treatment consisting of Trigger Points Therapy and kinesiotherapy represented an improvement in the quality of life with the regain of autonomy and selfconfidence. Trigger Points therapy can be used successfully to relieve symptoms such as migraines, muscle stiffness in the neck, diffuse or deep pain in the shoulder, tinnitus, vertigo, insomnia.

\section{References}

1. World Health Organization (2014), Varicella and herpes zoster vaccine: WHO position paper, Weekly epidemiological record, no.25, 265-288.

2. Gershon A., Breuer J., Cohen J. et al, (2015), Varicella zoster virus infection, Nature Reviews Disease Primers 1, 15016.

3. Sampathkumar P., Drage L.A., Martin D.P., (2009), Herpes Zoster (Shingles) and Postherpetic Neuralgia, Mayo Clinic Proceedings, 84 (3), 274-280.

4. Oxman M.N., Levin M.J., Johnson G.R., et al. (2005). A vaccine to prevent herpes zoster and postherpetic neuralgia in older adults, The New England Journal of Medicine, 352, 2271-2284.

5. Gershon A., (2017). Is chickenpox so bad, what do we know about immunity to varicella zoster virus, and what does it tell us about the future? Journal of Infection, 74(sup.1), S27-S33.
6. Whitley R.J., Middlebrooks M., Gnann J.W., (1990). Acyclovir: the past ten years, Advanced in Experimental Medicine and Biology, 278, 243-253.

7. Balfour H.H., Rotbart H., Feldman S., et al. (1992). Acyclovir treatment of varicella in otherwise healthy adolescents. The Journal of Pediatrics, 120(4), 627633.

8. Dunkel L., Arvin A., Whitley R., et al. (1991). A controlled trial of oral acyclovir for chickenpox in normal children, The New England Journalof Medicine, 325, 1539-1544.

9. Corti M., Trione N., Villafañe M.F., Daniel Risso D., Yampolsky C., Mamanna L., (2011). Acute meningoencephalomyelitis due to varicella-zoster virus in an AIDS patient: report of a case and review of the literature, Revista da Sociedade Brasileira de Medicina Tropical, 44(6), 784-786.

10. Cruz-Velarde J.A., Muñoz-Blanco J.L.,Traba A., Nevado C., Ezpeleta D., (2001). Segmental motor paralysis caused by the varicella zoster virus. Clinical study and functional prognosis, Revista de Neurologia, 32(1), 15-18.

11. Rueda O., Sandra Roberto A., Bolívar A., Lauren C., (2013 ). Partial Palsy of the Oculomotor Nerve Due to Zoster Sine Herpete: A Case Report, Revista de la Universidad Industrial de Santander, Salud, 45 (3), 77-80.

12. Serra V.M.A., Laurencio E.J.C., Valdés F.J.L., (2015). Acute transverse myelitis as a complication of the chickenpox. Case presentation, Revista Habanera de Ciencias Medicas, 14(2), 159-167

13. DeLaune V. (2008). Trigger Point Therapy for Headeaches \&Migrains

14. Kostopoulos D., Rizopoulos C., (2001). The Manual of Trigger Point and Miofascial Therapy

15. Chen W.H., Li T.H., Lee L.H., Huang C.C., (2012). Varicella-zoster Virus Infection and Nummular Headache: A Possible Association with Epicranial Neuralgia, Japonese Society of Internal Medicine, 51(17), 2439-2441.

16. Chaibi A., Tuchin P., Russell M.B., (2011). Manual therapies for migraine: a systematic review, Journal of Headache Pain, 12, 127-133. 